Tanjungpura Law Journal, Vol. 4, Issue 2, July 2020: 117 - 132

ISSN Print: 2541-0482 | ISSN Online: 2541-0490

Open Access at: http://jurnal.untan.ac.id/index.php/tlj

Article Info

Submitted: 30 April 2020 | Reviewed: 13 Juni 2020 | Accepted: 2 Juli 2020

\title{
ANALISIS RUU OMNIBUS LAW PERPAJAKAN TERHADAP PEMUNGUTAN PAJAK DAERAH
}

\author{
Maghfira Syalendri Alqadri ${ }^{1}$
}

\begin{abstract}
Condition of Indonesia's shrinking economic state made Indonesia's Goverment feels it is necessary to take concrete steps to increasing the national economic state by growing investment through deregulation aimed at resolving regulatory and bureaucratic problems, weak law enforcement, and business uncertainty that are a burden on industrial competitiveness and ease of doing business. Indoesia's Central Government through the Ministry of Finance in December 2019 endorsed the Draft of Tax Omnibus Law which is considered to be a solution to the condition of Indonesia. With regard to the regulation of regional tax rates in this regulation, it will be regulated simultaneously by the Central Government, on the other hand Regional governments have broad regional autonomy, not least in the regulation of local tax collection in their respective regions. The research uses normative juridical research to retrieve, analyze, and study the literature, scientific work, documents / archives and writings that are relevant to the research problem. The purpose of this study is to analyze the Tax Omnibus Law Bill in Indonesia. Based on these results it is known that the formation of the omnibus law can be done as long as it is formed based on existing laws and regulations. The impact of implementing the omnibus law on taxation can kill the sustainability and independence of regional autonomy.
\end{abstract}

Keywords: ease of doing business; omnibus law; regional tax; tax

\begin{abstract}
Abstrak
Dengan keadaan perekonomian yang semakin lesu, Pemerintah Indonesia merasa perlu melakukan langkah-langkah nyata untuk menggerakkan ekonomi nasional yakni dengan cara meningkatkan investasi melalui deregulasi yang bertujuan untuk menyelesaikan masalah regulasi dan birokrasi, lemahnya penegakan hukum, dan ketidakpastian usaha yang menjadi beban daya saing industri maupun kemudahan berusaha. Pemerintah Pusat melalui Kementerian Keuangan pada Desember 2019 mengesahkan Naskah RUU Omnibus Law Perpajakan yang dianggap dapat menjadi solusi akan kondisi Indonesia. Terhadap pengaturan tarif pajak daerah pada aturan ini akan diatur secara serentak oleh Pemerintah Pusat, di sisi lain Pemerintah Daerah memiliki otonomi daerah yang luas, tak terkecuali pada pengaturan pemungutan pajak daerah di wilayahnya masing-masing. Penelitian menggunakan penelitian yuridis normatif, yang akan mengambil, menganalisis, mempelajari dan menelaah literaturliteratur, karya ilmiah, dokumen/arsip dan tulisan yang relevan dengan permasalahan penelitian. Tujuan dari penelitian ini adalah menganalisis RUU Omnibus Law Perpajakan di Indonesia. Berdasarkan hasil penelitian tersebut diketahui bahwa pembentukan omnibus law dapat dilakukan sepanjang dibentuk berdasarkan dengan peraturan perundang-undangan yang sudah ada. Dampak dari dilaksanakannya omnibus law mengenai perpajakan ini dapat mematikan keberlangsungan maupun independensi dari otonomi daerah.
\end{abstract}

\section{Kata Kunci: kemudahan berusaha; omnibus law; pajak; pajak daerah}

${ }^{1}$ Fakultas Hukum, Universitas Indonesia, Jln. Salemba Raya No. 4 Jakarta, Indonesia, email: syalendri96@gmail.com, Tel/Fax.31909008/39899148. 


\section{Pendahuluan}

Perlambatan ekonomi di berbagai belahan dunia mengakibatkan penurunan konsumsi besar-besaran, turunnya permintaan dan harga komoditas, keluarnya Inggris dari Uni Eropa juga ikut menambah ketidakpastian pada pasar. Kejadian ini pun juga berpengaruh bagi Indonesia, perekonomian nasional pun menjadi melemah, kinerja sektor industri menjadi lesu, tingkat produksi, ekspor komoditas, penerimaan devisa maupun penerimaan negara pun ikut menurun ${ }^{1}$. Terhadap kondisi ini, pemerintah melakukan upaya untuk menggerakkan ekonomi nasional melalui 16 (enam belas) paket kebijakan ekonomi dengan cara deregulasi, debirokratisasi dan insentif fiskal. Menurut paket kebijakan ekonomi ini, salah satu cara untuk menggerakkan ekonomi nasional yakni dengan cara meningkatkan investasi.

Penyebab terhambatnya pengembangan kegiatan investasi di Indonesia diakibatkan adanya beban regulasi, birokrasi, dan penegakan hukum. Fokus utama dari 16 (enam belas) paket kebijakan ekonomi adalah kebijakan deregulasi untuk menyelesaikan masalah regulasi dan birokrasi, lemahnya penegakan hukum, dan ketidakpastian usaha yang menjadi beban daya saing

\footnotetext{
1 Kementerian Dalam Negeri Republik Indonesia. 2016. Menjaga Momentum, Meningktakan Kepercayaan, Paket Kebijakan Ekonomi (PKE). Available from: https://www.kemendag.go.id/files/pdf/2016/08/18/ menjaga-momentum-meningkatkan kepercayaanid0-1471493602.pdf. (Accessed November 28, 2019).
}

industri. Deregulasi bertujuan untuk mempermudah investasi sektor industri baik untuk pengembangan cabangcabang industri maupun untuk meningkatkan ekspor dan penyerapan tenaga kerja. ${ }^{2}$ Deregulasi ini dilakukan melalui perubahan aturan pelaksanaan kegiataan usaha pada Kementerian/Lembaga/Pemerintah

Daerah (K/L/D), tidak terkecuali pada pelaksanaan perpajakan di Indonesia. Sering kali egoisme sektoral atau departemen membuat suatu kebijakan ekonomi yang sebenarnya sangat baik dilihat dari isinya namun akhirnya menjadi tidak efektif karena adanya benturan dengan kebijakan-kebijakan lainnya. Kondisi seperti ini sering kali membuat para calon investor kebingungan yang pada akhirnya membatalkan niat mereka menanam modal di Indonesia.

Maka dari itu, Pemerintah Pusat melalui Kementerian Keuangan pada Desember 2019 mengesahkan Naskah Rancangan Undang-Undang (RUU) Omnibus Law tentang Ketentuan dan Fasilitas Perpajakan Untuk Penguatan Perekonomian $^{3}$ (selanjutnya ditulis RUU Omnibus Law Perpajakan) yang dianggap

\footnotetext{
2 Kementerian Koordinator Bidang Perekonomian Republik Indonesia. 2015. Perkembangan Pelaksanaan Kebijakan Deregulasi. Available from:

https://www.ekon.go.id/ekliping/view/sosialisasipaket-kebijakan.1740.html. (Accessed November 27, 2019).

3 Yusuf Imam Santoso. 2020. Sah! RUU Omnibus Law Perpajakan Berisi Sembilan Undang-Undang. Available from:https://nasional.kontan.co.id/news/sah-ruuomnibus-law-perpajakan-berisi-sembilan-undangundang. (Accessed March 30, 2020).
} 
dapat menjadi solusi terhadap peraturan perundang-undangan di bidang perpajakan yang pada saat ini belum dapat menampung perkembangan perekonomian dan hukum yang dinamis, terutama dalam perkembangan kegiatan investasi. Berdasarkan jurnal yang dibuat oleh Putu Eka Pitriyanti (2019), penerapan omnibus law bagi Indonesia dapat memberikan manfaat seperti menghilangkan tumpeng tindih antar peraturan perundang-undangan, efisiensi proses perubahan atau pencabutan peraturan perundangan-undangan dan menghilangkan ego sektoral yang terkandung dalam berbagai peraturan perundang-undangan. ${ }^{4}$ Teknik penyusunan peraturan menggunakan omnibus law berdasarkan penelitian yang dilakukan oleh Vincent Suriadinata, juga dapat diterapkan di Indonesia. ${ }^{5}$

Menteri Keuangan Indonesia, Sri Mulyani Indrawati, menyatakan bahwa omnibus law di bidang perpajakan ini hanya memuat 28 (dua puluh delapan) pasal dan terbagi dalam 6 (enam) cluster. Cluster pertama tentang cara meningkatkan investasi melalui penurunan tarif Pajak Penghasilan (PPh) Badan dan PPh bunga. Cluster kedua, sistem teritorial yaitu bagaimana penghasilan deviden luar negeri akan

${ }^{4}$ Putu Eka Pitriyantini. 2020. "Mewujudkan Kepastian Rancangan Undang-Undang Omnibus Law Bagi Kesejahteraan Masyarakat Indonesia", Majalah IImiah Universitas Tabanan 17(1): 61.

${ }^{5}$ Vincent Suriadinata. 2019. "Penyusunan UndangUndang Di Bidang Investasi: Kajian Pembentukan Omnibus Law Di Indonesia." Refleksi Hukum: Jurnal IImu Hukum 4(1): 1. dibebaskan pajak, asalkan diinvestasikan di Indonesia. Cluster ketiga mengenai subjek pajak Orang Pribadi (OP), yang mengatur OP Warga Negara Asing (WNA) dan Warga Negara Indonesia (WNI). Cluster keempat, tentang cara meningkatkan kepatuhan perpajakan yaitu mengatur ulang sanksi dan imbalan bunganya. Cluster kelima, untuk ekonomi digital, yaitu perpajakan transaksi elektronik yang dibuat sama dengan pajak biasa. Dan cluster keenam, adalah insentif-insentif pajak seperti tax holiday, super deduction, tax allowance, Kawasan Ekonomi Khusus (KEK), PPh untuk surat berharga, dan insentif pajak daerah dari Pemerintah Daerah (Pemda) ${ }^{6}$

Terkait insentif pajak daerah dari Pemda, Direktur Penyuluhan Pelayanan dan Hubungan Masyarakat Direktorat Jenderal Pajak (Ditjen Pajak), Hestu Yoga Saksama, mengungkapkan jika RUU Omnibus Law Perpajakan akan mengatur besaran tarif pajak yang sama atau fix rate. Hal tersebut bertujuan untuk mensinkronkan besaran pajak antara satu daerah dengan daerah lain, dan antara pusat dan daerah guna mendukung investasi. Pemerintah kemudian akan mereview pajak daerah yang dinilai menghambat investasi. Selain itu, pemerintah juga berencana akan

\footnotetext{
6 Fitria Novia Heriani. 2020. Omnibus Law Perpajakan Bakal Intervensi Aturan Pajak di Daerah. Available from: https://www.hukumonline.com/berita/baca/lt5e114f 2683adf/omnibus-law-perpajakan-bakal-intervensiaturan-pajak-di-daerah/. (Accessed March 30, 2020).
} 
menerapkan sanksi pengurangan dana transfer daerah bagi Pemda yang tidak mengikuti aturan di RUU Omnibus Law Perpajakan. $^{7}$

Di sisi lain, dengan diterbitkannya Undang-Undang Nomor 28 Tahun 2009 tentang Pajak Daerah dan Distribusi Daerah (UU PDRD), Pemda memiliki kewenangannya secara mandiri untuk menetapkan pajak daerah melalui Peraturan Daerah (Perda). Menurut Pasal 279, Pemerintah Pusat yang memiliki wewenang absolut dalam mengurus kebijakan moneter negara, telah menyerahkan dan/atau menugaskan kepada daerah terhadap pengaturan sumber penerimaan daerah, salah satunya dari pajak daerah. Dengan kondisi otonomi daerah di Indonesia yang menggunakan sistem desentralisasi, yakni penyerahan wewenang pemerintahan oleh pemerintah ke daerah otonom untuk mengatur dan mengurus urusan pemerintahan dalam sistem Negara Kesatuan Republik Indonesia (NKRI), ${ }^{8}$ memiliki artian bahwa Pemda memiliki kewenangannya sendiri mengenakan pajak di daerahnya. Idealnya, dalam melaksanakan otonomi daerah, Pemda harus bertumpu pada sumber-sumber dari daerahnya sendiri. ${ }^{9}$

\footnotetext{
7 Ibid.

${ }^{8}$ Arum Sutrisni Putri. 2019. Pengertian Otonomi Daerah dan Dasar Hukumnya. Available from: https://www.kompas.com/skola/read/2019/12/16/1 10000069/pengertian-otonomi-daerah-dan-dasarhukumnya?page=all. (Accessed March 30, 2020).

9 Tjip Ismail, Hukum Pajak, [s.1:s.n., 2018] hlm. 10.
}

Melalui tulisan ini, akan dibahas beberapa hal seperti dasar hukum diberlakukannya omnibus law di Indonesia, sistem pemungutan pajak daerah berdasarkan RUU Omnibus Law Perpajakan dan menurut sistem saat ini serta dibuat perbandingannya akan kedua sistem tersebut. Lalu ditelaah juga mengenai dampak apa saja yang timbul dari diselenggarakannya RUU Omnibus Law Perpajakan. Sehingga sangat penting disini untuk melakukan penelitian lebih lanjut, apakah omnibus law ini dapat diberlakukan dengan cara Pemerintah Pusat yang sebelumnya telah menyerahkan sebagian wewenangnya ke Pemda lalu menariknya kembali. Penulisan jurnal ini juga penting dilakukan untuk menambah tulisan-tulisan ilmiah mengenai omnibus law, khususnya di bidang perpajakan yang masih jarang.

\section{Metode}

Penelitian yang akan dilakukan oleh Penulis merupakan penulisan yuridis normatif, yaitu "Penelitian hukum yang dilakukan dengan cara meneliti bahan pustaka atau data sekunder sebagai bahan dasar untuk diteliti dengan cara mengadakan penelusuran terhadap peraturan-peraturan dan literatur-literatur yang berkaita dengan permasalahan yang diteliti."10 Penelitian hukum normatif memiliki ciri-ciri yakni deskriptif analitis dengan pendekatan yuridis normatif;

\footnotetext{
10 Soerjono Soekanto \& Sri Mamudji, 1995. Penelitian Hukum Normatif. Jakarta: Raja Grafindo Persada, hlm. 13.
} 
konsep, perspektif, teori dan paradigma yang menjadi landasan teoritis penelitian mengacu pada kaidah hukum yang ada dan berlaku atau pada ajaran hukum dari para pakar hukum; analisis data dilakukan secara kualitatif; beranjak dari adanya kesenjangan dalam norma/asas hukum; dan tidak menggunakan hipotesis. Penelitian ini dilakukan bertujuan untuk menganalisa dampak dari implementasi RUU Omnibus Law Perpajakan di Indonesia.

Dalam pengumpulan data yang dilakukan dalam penelitian ini adalah penelitian kepustakaan (Library Research). ${ }^{11}$ Oleh karena itu, teknik yang digunakan dalam pengumpulan data pada penelitian ini adalah teknik studi dokumen yaitu teknik awal yang digunakan dalam setiap penelitian hukum. Studi dokumen dilakukan atas bahan-bahan hukum, mengambil, menganalisis, mempelajari dan menelaah literatur-literatur, karya ilmiah, dokumen/arsip dan tulisan yang relevan dengan permasalahan penelitian. Studi dokumen dapat diperoleh melalui: Bahan Hukum Primer, yaitu bahan-bahan hukum yang mengikat; Bahan Hukum Sekunder, yakni Bahan-bahan yang memberikan penjelasan mengenai bahan hukum primer yaitu hasil-hasil penelitian, buku-buku hukum dan hasil karya dari kalangan para ahli hukum; dan Bahan Hukum Tersier, yakni bahan-bahan yang

11 Mustika Zed. 2004. Metode Penelitian Kepustakaan. Jakarta: Yayasan Obor Nasional, hlm. 2-3 memberikan petunjuk maupun penjelasan terhadap bahan hukum primer dan sekunder yakni berupa kamus dan ensiklopedia.

\section{Analisis dan Pembahasan}

\section{A. Pengaturan Pajak Daerah dalam RUU Omnibus Law Perpajakan}

Konsep Omnibus Law atau di Amerika Serikat lebih dikenal dengan sebutan Omnibus Bill ini, menurut Bryan A. Garner pada Black's Law Dictionary Ninth Edition, diartikan sebagai " $A$ single bill containing various distinct matters, usu. drafted in this way to force the executive either to accept all the unrelated minor provisions or to veto the major provision" atau sebuah undang-undang yang mengatur dan mencakup berbagai jenis materi muatan yang berbeda-beda atau mengatur dan mencakup semua hal mengenai suatu jenis materi muatan. ${ }^{12}$ Penerapan metode omnibus law pun telah dilakukan setidaknya oleh 9 (sembilan) negara yakni Inggris, Australia, Jerman, Turki, Filipina, Kamboja, Vietnam, Malaysia dan Singapura.

Pada Undang-Undang Nomor 12 Tahun 2011 tentang Pembentukan Peraturan Perundang-Undangan (UU PPPU) memang tidak dimuat bentuk perundang-undangan seperti metode omnibus law, namun dalam rangka

\footnotetext{
${ }^{12}$ Arasy Pradana A. Azis. 2019. Mengenal Omnibus Law dan Manfaatnya dalam Hukum Indonesia. Avalable from: https://www.hukumonline.com/klinik/detail/tt5dc8ee 10284ae/mengenal-omnibus-law-dan-manfaatnyadalam-hukum-indonesia/. (Accessed April 29, 2020).
} 
menghilangkan beban regulasi yang ada akibat overlapping atau tumpang tindih antar aturan-aturan yang ada, maka pemerintah melakukan deregulasi yang dilaksanakan melalui perubahan aturan pelaksanaan kegiataan usaha pada Kementerian/Lembaga/Pemda (K/L/D) ${ }^{13}$, dituangkan ke dalam bentuk sebuah aturan yang mencakup suatu jenis materi muatan yakni omnibus law. Deregulasi melalui produk omnibus law memiliki beberapa tujuan seperti menyelaraskan berbagai aturan yang inkonsistensi, menyederhanakan regulasi, mempermudah investasi dan meningkatkan pertumbuhan ekonomi demi kesejahteraan masyarakat. ${ }^{14}$

Namun, bentuk aturan omnibus law tak sepenuhnya baru dikenal oleh Indonesia. Terlepas dari soal istilah, substansi omnibus law sudah pernah digunakan dalam legislasi yakni pada Peraturan Pemerintah Pengganti Undangundang No.1 Tahun 2017 tentang Akses Informasi untuk Kepentingan Perpajakan/Automatic Exchange of Information-AEol) (Perppu AEol) dan Undang-undang No. 23 Tahun 2014 tentang Pemerintahan Daerah (UU Pemda $)^{15}$ Melalui deregulasi tersebut,

${ }^{13}$ Permenko Bidang Perekonomian Nomor 8 Tahun 2017 tentang Pedoman Pelaksanaan Perpres Nomor 91 Tahun 2017 tentang Percepatan Pelaksanaan Berusaha, hlm. 12

${ }^{14}$ Cecep Darmawan. 2020. Omnibus Law Untuk Siapa. Available from: https://mediaindonesia.com/read/detail/296862omnibus-law-untuk-siapa. (Accessed from July 19, 2020).

${ }^{15}$ M-30. 2020. Menelusuri Asal-Usul Konsep Omnibus Law. Available from:
RUU Omnibus Law Perpajakan ini ditargetkan dapat mencapai kondisi perekonomian di Indonesia yang lebih baik dengan cara meningkatkan investasi dan iklim usaha yang kondusif, mendorong pertumbuhan industri atau usaha yang berdaya saing tinggi, dan memberikan perlindungan serta pengaturan yang berkeadilan. ${ }^{16}$

Selain pengaturan dan fasilitas perpajakan nasional, RUU Omnnibus Law Perpajakan juga memuat ketentuan maupun fasilitas perpajakan daerah guna mendukung kebijakan perkenomian nasional. Fasilitas perpajakan yang dimaksud pada RUU ini berupa keringanan, pengurangan, atau pembebasan pajak daerah, diatur melalui Peraturan Kepala Daerah. Penentuan tarif atas pajak daerah dilakukan berskala nasional dan sama (fix rate) oleh Pemerintah Pusat yang dibuat melalui Peraturan Presiden (Perpres), sehingga terhadap adanya perbedaan tarif pajak daerah yang telah ditentukan oleh Perda dapat diganti oleh Pemerintah Pusat. Penentuan tarif berskala nasional dimaksudkan agar Pemerintah Pusat dapat melakukan pengawasan maupun evaluasi terhadap Perda maupun rancangannya mengenai pajak daerah yang dapat menghambat kemudahan dalam berusaha. Setalah dikeluarkan penetapan tarif pajak melalui Perpres,

https://www.hukumonline.com/berita/baca/lt5e2c1e 4de971a/menelusuri-asal-usul-konsep-omnibuslaw/. (Accessed from April 29, 2020).

16 Pembukaan RUU Omnibus Law Perpajakan. 
Pemda wajib menetapkan tarif tersebut paling lambat 3 (tiga) bulan.

Rancangan Perda pada wilayah Provinsi/Kabupaten/Kota mengenai pajak daerah dan retribusi daerah yang telah disetujui bersama Dewan Perwakilan Rakyat Daerah (DPRD) sebelum ditetapkan oleh gubernur/bupati/walikota wajib disampaikan kepada Menteri Keuangan, yang tugasnya melakukan evaluasi Rancangan Perda untuk menguji kesesuaian antara rancangan tersebut dengan ketentuan peraturan perundangundangan yang lebih tinggi dan kebijakan fiskal nasional, dan Menteri Dalam Negeri yang bertugas untuk mengevaluasi Rancangan Perda sesuai dengan ketentuan yang ada. Perda maupun aturan pelaksananya yang sudah ditetapkan wajib disampaikan ke Menteri Keuangan dan Menteri Dalam Negeri paling lama 7 (tujuh) hari setelah ditetapkan. Lalu apabila evaluasi terhadap Perda maupun aturan turunannya memuat unsur-unsur yang menghambat kemudahan dalam berusaha, maka Pemda wajib melalukan perubahan aturan tersebut paling lama 6 (enam) bulan sejak hasil evaluasi terbit. Pengaturan administratif ketentuan dan fasilitas perpajakan di atas dianggap dapat mampu memberikan solusi dan pencegahan terhadap adanya aturan yang saling tumpang tindih dan mencegah ke udahan dalam melakukan bisnis maupun investasi. Pelanggaran administratif aturan perpajakan ini dapat memberikan sanksi berupa penundaan dan/atau pemotongan dana transfer ke daerah dan/atau sanksi lain sesuai peraturan perundang-undangan. Terhadap keberadaan serta status hukum dari UU PDRD sebelumnya masih berlaku sepanjang tidak bertentangan dengan RUU ini.

\section{B. Sistem Pemungutan Pajak Daerah Saat Ini}

Pengaturan akan sistem pemerintahan daerah di Indonesia dimuat di Undang-Undang Dasar Republik Indonesia Tahun 1945 (UUD 1945) bahwa terhadap NKRI, dibagi daerah-daerahnya atas provinsi, lalu dibagi lagi menjadi kabupaten dan kota, yang memiliki wewenang untuk mengatur maupun mengurus sendiri urusan pemerintahan menurut asas otonomi dan tugas pembantuan (medebewind). Pemda dengan otonomi adalah proses peralihan sistem dekonsentrasi ${ }^{17}$ ke sistem desentralisasi ${ }^{18}$.

Otonomi adalah penyerahan urusan Pemerintah Pusat kepada Pemda yang bersifat operasional dalam rangka sistem birokrasi pemerintahan. Tujuan otonomi adalah mencapai efisiensi dalam

\footnotetext{
17 Pasal 1 angka 9 UU Pemda: "Dekonsentrasi adalah pelimpahan sebagian Urusan Pemerintahan yang menjadi kewenangan Pemerintah Pusat kepada gubernur sebagai wakil Pemerintah Pusat, kepada instansi vertikal di wilayah tertentu, dan/atau kepada gubernur dan bupati/wali kota sebagai penanggung jawab urusan pemerintahan umum."

18 Menurut Pasal 1 angka 8: "penyerahan Urusan Pemerintahan oleh Pemerintah Pusat kepada daerah otonom berdasarkan Asas Otonomi."
} 
pelayanan kepada masyarakat. $^{19}$ Pengertian otonomi daerah juga dimuat pada Pasal 1 angka 6 UU Pemda yaitu: "Otonomi daerah adalah hak, wewenang, dan kewajiban daerah otonom untuk mengatur dan mengurus sendiri Urusan Pemerintahan dan kepentingan masyarakat setempat dalam sistem Negara Kesatuan Republik Indonesia". Daerah memiliki wewenangnya untuk mengatur dan mengurus kepentingan masyarakat setempat menurut prakasa sendiri berdasarkan aspirasi masyarakat, sesuai dengan peraturan perundangundangan. Dalam menjalankan otonomi beserta tugas pembantuannya ini, Pemda berhak untuk menetapkan Perda atau peraturan-peraturan lain. ${ }^{20}$

Namun, walaupun pemberian otonomi kepada daerah dilakukan seluasluasnya, dengan digunakannya prinsip negara kesatuan, kedaulatan hanya ada pada pemerintahan negara atau pemerintahan nasional dan tidak terdapat kedaulatan pada daerah. Sehingga, seluas apa pun otonomi daerah, tanggung jawab akhir penyelenggaraan Pemda akan tetap berada di tangan Pemerintah Pusat. ${ }^{21}$

Sejalan dengan penyerahan urusan, apabila urusan tersebut menjadi beban daerah, maka akan dilaksanakan melalui

19 Via Eviana. 2015. "Analisis Kebijakan Pengalihan PBB P-2 di Kota Metro". Skripsi Fakultas Ekonomi dan Bisnis, Universitas Lampung, Lampung: 16.

20 Pasal 18 ayat 6 UUD 1945.

${ }^{21}$ Sri Kusriyah. 2016. "Politik Hukum Penyelenggaraan Otonomi Daerah dalam Perspektif Negara Kesatuan Republik Indonesia", Jurnal Pembaharuan Hukum, 3(3): 3. asas pembantuan. Proses dari sentralisasi ke desentralisasi pada dasarnya tidak semata-mata desentralisasi administratif, tetapi juga bidang politik dan sosial budaya. Dengan demikian pemberian otonomi ini tidak hanya terjadi pada organisasi atau administratif lembaga Pemda saja, akan tetapi berlaku juga pada masyarakat (publik), badan atau lembaga swasta dalam berbagai bidang. Dengan otonomi ini terbuka kesempatan bagi Pemda secara langsung membangun kemitraan dengan publik dan pihak swasta daerah yang bersangkutan dalam berbagai bidang. ${ }^{22}$

Pemda yang masing-masing daerahnya dikepalai gubernur, bupati dan walikota, dapat menjalankan otonomi seluas-luasnya, kecuali urusan pemerintah yang oleh UU ditentukan sebagai urusan Pemerintah Pusat. Urusan Pemerintah pada UU Pemda diartikan sebagai kekuasaan pemerintahan yang menjadi kewenangan Presiden yang pelaksanaannya dilakukan oleh kementerian negara dan penyelenggara Pemda untuk melindungi, melayani, memberdayakan, dan menyejahterakan masyarakat. $^{23}$

Urusan pemerintahan terdiri atas urusan pemerintahan absolut yang sepenuhnya menjadi kewenangan Pemerintah Pusat, meliputi pertahanan, keamanan, yustisi, moneter dan fiskal

22 H.A.W Widjaja. 2002. Otonomi Daerah dan Daerah Otonom. Jakarta: PT Raja Grafindo Persada, hlm. 76-77.

${ }^{23}$ Pasal 1 Angka 5 UU Pemda. 
nasional serta agama; urusan pemerintahan konkuren yang wewenangnya dibagi antara Pemerintah Pusat dan Pemda, terdiri dari urusan pemerintahan wajib yang berkaitan dengan pelayanan dasar yang berkaitan dengan pelayanan dasar meliputi pendidikan, kesehatan, pekerjaan umum dan penataan ruang, perumahan rakyat dan kawasan pemukiman, ketenteraman, ketertiban umum dan perlindungan masyarakat serta sosial, lalu urusan yang tidak berkaitan dengan pelayanan dasar yakni tenaga kerja, pemberdayaan perempuan dan pelindungan anak, pangan, pertanahan, lingkungan hidup, administrasi kependudukan dan pencatatan sipil, pemberdayaan masyarakat dan desa, pengendalian penduduk dan keluarga berencana, perhubungan, komunikasi dan informatika, koperasi, usaha kecil, dan menengah, penanaman modal, kepemudaan dan olah raga, statistik, persandian, kebudayaan, perpustakaan dan kearsipan, serta urusan pemerintahan pilihan yakni kelautan dan perikanan, pariwisata, pertanian, kehutanan, energi dan sumber daya mineral, perdagangan, perindustrian, transmigrasi; dan urusan pemerintahan umum yang menjadi kewenangan presiden sebagai kepala pemerintahan. ${ }^{24}$

Terhadap pembiayaan penyelenggaraan urusan pemerintah yang telah dibahas pada paragraf sebelumnya,

\footnotetext{
24 Pasal 9-12 UU Pemda.
}

terbentuklah suatu hubungan, yaitu hubungan keuangan antara pemerintah pusat dengan Pemda yang didanai oleh Anggaran Pendapatan Belanja Negara $(\mathrm{APBN})^{25}$. Yang dimaksud dnegan hubungan keuangan pada Pasal 1 angka 30 UU Pemda, "Hubungan Keuangan antara Pemerintah Pusat dan Daerah adalah suatu sistem pembagian keuangan yang adil, proporsional, demokratis, transparan dan bertanggung jawab". Hubungan keuangan dalam penyelenggaraan Urusan Pemerintahan yang diserahkan kepada daerah meliputi: pemberian sumber penerimaan daerah berupa pajak daerah dan retribusi daerah; pemberian dana bersumber dari perimbangan keuangan antara Pemerintah Pusat dan Pemda; pemberian dana penyelenggaraan otonomi khusus untuk Pemerintahan Daerah tertentu yang ditetapkan dalam undang-undang; dan pemberian pinjaman dan/atau hibah, dana darurat, dan insentif. ${ }^{26}$ Penyerahan urusan keuangan dari Pemerintah Pusat ini juga dikenal dengan sistem tax assignment atau kewenangan perpajakan daerah. Pemerintah daerah idealnya memprioritaskan pemenuhan fungsi alokasi dengan menyediakan pelayanan yang bermanfaat bagi masyarakat setempat yang biayanya ditanggung oleh masyarakat setempat sehingga instrument

\footnotetext{
25 Pasal 4 Undang-Undang Nomor 33 Tahun 2004 tentang Perimbangan Keuangan Antara Pemerintah Pusat dan Pemerintah Daerah (UU PKPPPD).

${ }^{26}$ Pasal 279 UU Pemda.
} 
perpajakan yang dibuat oleh daerah setempat sangatlah diperlukan. Tax assignment dikaitkan dengan otonomi fiskal dapat dibedakan menjadi 3 (tiga), yaitu terkait dengan penentuan basis pajak, penetapan tarif dan administrasi pajak. $^{27}$

Pengaturan akan pemungutan pajak daerah, sebelumnya telah dilakukan pada periode masa awal kemerdekaan melalui ordonansi pajak dan retribusi daerah masa penjajahan Belanda dan Jepang yang masih berlaku. ${ }^{28}$ Pengaturan akan pajak daerah sekarang diatur pada UU PDRD. Apabila dilihat pada Pasal 1 angka 10, pengertian pajak daerah adalah kontribusi wajib kepada Daerah yang terutang oleh orang pribadi atau badan yang bersifat memaksa berdasarkan Undang-Undang, dengan tidak mendapatkan imbalan secara langsung dan digunakan untuk keperluan daerah bagi sebesar-besarnya kemakmuran rakyat.

Basis pajak pada UU PDRD mengalami perluasan dibandingkan dengan aturan sebelumnya UndangUndang Nomor 28 Tahun 2009, yakni adanya perluasan jenis pajak rokok dan ditambahkannya jenis pajak air tanah, pajak sarang burung wallet, pajak PBB perdesaan/perkotaan dan BPHTB untuk

\footnotetext{
27 Naskah Akademik Rancangan Undang-Undang tentang Ketentuan dan Fasilitas Perpajakan untuk Penguatan Perekonomian, hlm. 50.

28 Tjip Ismail. 2018. Potret Pajak Daerah di Indonesia. Jakarta: Prenadamedia Group, hlm. 61.
}

daerah kabupaten/kota. ${ }^{29}$ Sehingga jenisjenis pajak menururt UU PDRD dibagi atas pajak provinsi yang terdiri dari Pajak Kendaraan Bermotor (PKB);Bea Balik Nama Kendaraan Bermotor (BBNKB); Pajak Bahan Bakar Kendaraan Bermotor (PBB KB); Pajak Air Permukaan; dan Pajak Rokok ${ }^{30}$, serta pajak kabupaten/kota terdiri atas Pajak Hotel; Pajak Restoran; Pajak Hiburan; Pajak Reklame; Pajak Penerangan Jalan (PPJ); Pajak Mineral Bukan Logam dan Batuan; Pajak Parkir; Pajak Air Tanah; Pajak Sarang Burung Walet; Pajak Bumi dan Bangunan Perdesaan dan Perkotaan (PBB Pedesaan dan Perkotaan); dan Bea Perolehan Hak atas Tanah dan Bangunan (BPHTB). ${ }^{31}$

Lalu UU PDRD juga memberikan penetapan tarif batas atas maupun batas bawah pada masing-masing jenis pajak daerah provinsi maupun kabupaten/kota. UU PDRD juga memberikan kewenangan kepada Pemda untuk mengatur pajak daerah maupun retribusi daerah melalui Perda. Terhadap pengaturan mengenai pengawasan maupun pembatalan Rancangan Perda dan Perda yang memuat pajak daerah dan retribusi daerah yang dimuat pada Pasal 157, pasal 158 ayat (2) sampai dengan ayat (9) dan Pasal 159 UU PDRD sudah tidak berlaku lagi, sehingga yang masih berlaku hanyalah pengaturan yang memuat

\footnotetext{
29 Tjip ismail, op. cit., hlm. 157.

${ }^{30}$ Pasal 2 ayat (1) UU PDRD.

${ }^{31}$ Pasal 2 ayat (2) UU PDRD.
} 
instruksi untuk disampaikannya Perda kepada Menteri Keuangan dan Menteri Dalam Negeri paling lama 7 (hari) kerja setelah ditetapkan yang dimuat pada Pasal 158 ayat (1).

Sedangkan tata cara pemungutan pajak dilakukan diatur pada Pasal 96 UU PDRD: (1) Pemungutan Pajak dilarang diborongkan; (2) Setiap Wajib Pajak wajib membayar Pajak yang terutang berdasarkan surat ketetapan pajak atau dibayar sendiri oleh Wajib Pajak berdasarkan peraturan perundangundangan perpajakan; (3) Wajib Pajak yang memenuhi kewajiban perpajakan berdasarkan penetapan Kepala Daerah dibayar dengan menggunakan SKPD ${ }^{32}$ atau dokumen lain yang dipersamakan; (4) Dokumen lain yang dipersamakan berupa karcis dan nota perhitungan; dan (5) Wajib Pajak yang memenuhi kewajiban perpajakan sendiri dibayar dengan menggunakan SPTPD ${ }^{33}$, SKPDKB $^{34}$, dan/atau SKPDKBT ${ }^{35}$. Inti sari

32 Pasal 1 angka 53 UU PDRD: "Surat Ketetapan Pajak Daerah, yang selanjutnya disingkat SKPD, adalah surat ketetapan pajak yang menentukan besarnya jumlah pokok pajak yang terutang."

33 Pasal 1 angka 50 UU PDRD: "Surat Pemberitahuan Pajak Daerah, yang selanjutnya disingkat SPTPD, adalah surat yang oleh Wajib Pajak digunakan untuk melaporkan penghitungan dan/atau pembayaran pajak, objek pajak dan/atau bukan objek pajak, dan/atau harta dan kewajiban sesuai dengan ketentuan peraturan perundangundangan perpajakan daerah".

${ }^{34}$ Pasal 1 angka 55 UU PDRD: "Surat Ketetapan Pajak Daerah Kurang Bayar, yang selanjutnya disingkat SKPDKB, adalah surat ketetapan pajak yang menentukan besarnya jumlah pokok pajak, jumlah kredit pajak, jumlah kekurangan pembayaran pokok pajak, besarnya sanksi administratif, dan jumlah pajak yang masih harus dibayar".

35 Pasal 1 angka 56 UU PDRD: "Surat Ketetapan Pajak Daerah Kurang Bayar Tambahan, yang dari Pasal 96 ini adalah berupa tata cara pengenaan pajak daerah yang diatur dalam UU PDRD melalui 2 (dua) cara: pertama, ditetapkan oleh kepala daerah; atau kedua, dibayar sendiri oleh wajib pajak yang bersangkutan. ${ }^{36}$

Dalam melaksanakan pungutan pajak daerah tersebut, daerah dilarang memungut pajak selain pajak yang yang dimaksud pada UU PDRD atau bersifat terbatas (limitatif). Selain itu, daerah juga tidak memungut jenis pajak tertentu apabila potensinya kurang memadai dan/atau disesuaikan dengan kebijakan daerah yang ditetapkan dengan Perda ${ }^{37}$, contohnya seperti di Kabupaten Mimika tidak ada pajak sarang burung walet karena memang tidak ada sarang burung walet. $^{38}$

Seiring dengan tujuan otonomi daerah yang mendekatkan pelayanan pemerintah dengan rakyatnya, maka fungsi pajak daerah tidak semata-mata untuk mengisi kas daerah (APBD) saja, namun dalam definisi pajak sebagai pengisi kas daerah, titik berat pajak diletakkan pada fungsi budgeter meskipun terdapat fungsi lain, yaitu fungsi mengatur (regulerend). Dari kedua fungsi pajak tersebut yang lebih mendekati makna otonomi daerah dan harus lebih dieksploitasi atau dikembangkan adalah fungsi mengatur atau budgeter, yang

selanjutnya disingkat SKPDKBT, adalah surat ketetapan pajak yang menentukan tambahan atas jumlah pajak yang telah ditetapkan".

36 Tjip ismail, op. cit., hlm. 140.

${ }^{37}$ Pasal 2 ayat (3) UU PDRD.

38 Tjip ismail, op. cit., hlm. 157. 
dalam hal ini berkaitan erat dengan upaya meningkatkan pelayanan. ${ }^{39}$

Hal tersebut sesuai pula dengan teori welfare state dan teori utility, bahwa pungutan pajak daerah hendaknya memenuhi rasa keadilan dan ditujukan untuk kemanfaatan dan kesejahteraan masyarakat. ${ }^{40}$ Pengertian welfare state atau negara kesejahteraan tidak dapat dipisahkan dari konsep mengenai kesejahteraan atau welfare. Pengertian kesejahteraan sedikitnya mengandung 4 (empat) makna: sebagai kondisi sejahtera (well being); sebagai pelayanan sosial; sebagai tunjangan sosial; dan sebagai proses terencana yang dilakukan oleh perorangan, lembaga-lembaga sosial, masyarakat maupun badan-badan pemerintah untuk meningkatkan kualitas kehidupan melalui pemberian pelayanan sosial dan tunjangan sosial. ${ }^{41}$ Sedangkan teori utility atau kemanfaatan, pajak dalam pengelolaanya, perlu disesuaikan sedemikian rupa sehingga dapat memenuhi rasa adil pada masyarakat. ${ }^{42}$

Berdasarkan uraian di atas, dapat dilihat beberapa perbedaan muatan pada UU PDRD maupun RUU Omnibus Law Perpajakan. Pertama, melalui RUU Omnibus Law Perpajakan, tarif pajak ditentukan oleh pemerintah pusat secara

39 Ibid, hlm. 139.

40 lbid

41 Ainur Rofieq. 2011. "Pelayan Publik dan Welfare State". Governance: Jurnal IImu Pemerintahan, 2(1): 102.

42 Tjip Ismail. 2011. Analisis dan Evaluasi UU No. 28 Tahun 2009 tentang Pajak Daerah dan Retribusi Daerah. Jakarta: Badan Pembinaan Hukum Nasional, hIm. 6. nasional dan sama (fix rate), berbeda dengan UU PDRD yang hanya memberikan kisaran maksimum maupun minimum pengenaan tarif masing-masing pajak daerah. Kedua, adanya unsur menghambat kemudahan dalam melakukan usaha dapat membuat Rencana Perda maupun Perda pajak daerah yang sudah ada menjadi dibatalkan, sedangkan pada UU PDRD, pembatalan aturan ditekankan kepada muatan dari aturan tersebut melanggar kepentingan umum. Ketiga, penetapan tarif jenis-jenis pajak daerah dilakukan melalui Perda, sedangkan apabila RUU Omnibus Law Perpajakan diberlakukan, tata cara penetapan tarifnya diatur melalui Perpres.

Seyogyanya UU PDRD memang memerlukan perubahan pada muatannya. Selain untuk memudahkan kemudahan berusaha, namun juga perlu mengikuti perubahan UU Pemda terbaru yang diundangkan pada tahun 2014, sehingga pengaturan pajak daerah maupun retribusi daerah dapat dijalankan sesuai dengan asas-asas yang dipegang pada UU Pemda sekarang ini. Akan tetapi, dampak akibat diberlakukannya RUU Omnibus Law Perpajakan juga dapat timbul, seperti dapat mempengaruhi eksistensi keberlangsungan Pemda dan kemandiriannya menjalankan otonomi daerah. Dengan digunakannya asas otonomi seluas-luasnya dan penyerahan tugas pembantuan oleh Pemerintah Pusat, Pemda dapat mengatur dan 
mengurus rumah tangganya sendiri agar dapat lebih mendekatkan pelayanan dari pemerintah kepada masyarakat, memudahkan masyarakat untuk memantau dan mengontrol penggunaan dana yang bersumber dari APBD. Pemda juga diharapkan dapat mampu secara mandiri untuk menggali sumber-sumber keuangan khususnya untuk memenuhi kebutuhan pembiayaan pemerintahan dan pembangunan di daerahnya melalui Pendapatan Asli Daerah (PAD). ${ }^{43}$

Diundangkannya RUU Omnibus Law Perpajakan melanggar keberadaan akan kedua fungsi tersebut sehingga tidak dapat dilaksanakan dengan baik. Aturan tersebut juga berpotensi mengurangi PAD, padahal disisi lain Pemda juga dituntut agar dapat secara independen mencari cara untuk mengisi dana mereka demi keberlangsungan dan kemaslahatan daerah. Perlu juga menjadi catatan, penyelanggaraan otonomi yang seluasluasnya tidak membuat Pemda secara sewenang-wenang mengatur keuangan daerahnya sebab tanggung jawab akhir penyelenggaraan Pemda akan tetap berada di tangan Pemerintah Pusat.

RUU Omnibus Law Perpajakan juga tidak mendukung keberlangsungan welfare state dan utility, sebab masingmasing daerah memiliki kemampuan yang berbeda terhadap pembayaran pajak

\footnotetext{
${ }^{43}$ Machfud Sidiq. 2002. "Optimalisasi Pajak Daerah dan Retribusi Daerah dalam Rangka Meningkatkan Kemampuan Keuangan Daerah". Makalah disampaikan pada Acara Orasi IImiah, Bandung: 1.
}

daerah, sehingga dengan ditetapkannya tarif pajak daerah sebelumnya , menimbulkan ketidakadilan bagi masyarakat. Dengan ketiadaan kewenangan Pemda dalam menetapkan dan menyesuaikan tarif pajak daerah akan menimbulkan masalah dalam menyesuaikan penerimaan dengan pengeluaran yang memberikan tingkat (kualitas dan kuantitas) pelayanan yang sesuai dengan prefereni masyarakat setempat. ${ }^{44}$ Lebih dikedepankannya unsur "kemudahan berusaha" dibandingkan "kepentingan umum" sebagai syarat dibatalkan Perda maupun Rancangan Perda Pajak Daerah dan Retribusi Daerah mengindikasikan tidak dikedepankannya prinsip dari utility atau kemanfaatan atas aturan tersebut. Aturan diberlakukan semata-mata hanya untuk menaikkan tingkat perekonomian nasional saja, padahal di sisi lain kemungkinan dilanggarnya prinsip-prinsip kepentingan umum juga dapat dilanggar.

\section{Penutup}

Keberadaan bentuk perundangundangan seperti omnibus law memang tidak dimuat secara eksplist pada UU PPPU, namun di sisi lain juga tidak ada larangan bagi pembentukan omnibus law yang mengakomodasi aturan-aturan yang ada mengenai suatu muatan aturan tertentu, sepanjang pembuatan dari omnibus law tetap berada pada koridor

\footnotetext{
44Tjip Ismail, Potret Pajak Daerah, hlm. 174.
} 
aturan yang ada. ${ }^{45}$ Dengan diundangkannya RUU Omnibus Law Perpajakan berpotensi mematikan keberlangsungan maupun independensi dari otonomi daerah. Sebab terhadap penentuan tarif pajak per daerah, menurut aturan RUU ini, Pemerintah Pusat lah yang mengatur tarif pajak daerah secara nasional dan sama (fix rate). Nyatanya, pihak yang paling mengerti ataupun mengenal potensi maupun karakteristik dari daerahnya adalah Pemda itu sendiri. Dengan diundangkannya RUU ini, Pemda menjadi memiliki ketergantungan pada Pemerintah Pusat dalam menjalankan otonomi daerah, mencegah daerah untuk bereksplorasi dalam mengembangkan daerahnya sendiri, mengurangi $P A D$ daerah masing-masing dan juga menyulitkan upaya Pemda dalam memberikan pelayanan yang maksimal untuk masyarakat. Solusi terbaik yang dapat dilakukan oleh Pemerintah Pusat terhadap pembuatan RUU Omnibus Law Perpajakan guna memajukan kondisi perkekonomian Indonesia yakni dengan membentuk tim khusus untuk menganalisa regulasi apa saja yang perlu harmonisasi sehingga aturan mengenai pajak maupun retribusi daerah yang baru dapat sesuai dengan UU Pemda dan dengan peraturan perundangan-undangan lainnya. ${ }^{46}$

\footnotetext{
45 Arasy Pradana, op. cit.

${ }^{46}$ Agnes Fitryantica. 2019. "Harmonisasi Peraturan Perundang-Undangan Indonesia Melalui Konsep Omnibus Law', Jurnal Gema Keadilan, 6(3): 303.
}

Tim khusus tersebut perlu menjembatani antara Kementerian Keuangan dengan Kementerian Dalam Negeri kaitannya dengan evaluasi maupun pengawasan aturan pajak daerah, sebab mengandalkan kerja antar kementerian dapat menelan waktu cukup lama. Agar tetap dapat menjujung asas otonomi daerah namun juga mendukung ruang gerak Pemerintah Pusat dalam mengendalikan kebijakan fiskal secara nasional, penetapan tarif pajak daerah dapat ditetapkan batasnya (limit) pengeluaran/belanja daerah yang dapat ditoleransi. ${ }^{47}$

\section{Bibliografi}

\section{Buku:}

H.A.W Widjaja. 2002. Otonomi Daerah dan Daerah Otonom. Jakarta: PT Raja Grafindo Persada.

Mustika Zed. 2004. Metode Penelitian Kepustakaan, Jakarta: Yayasan Obor Nasional.

Soerjono Soekanto dan Sri Mamudji. 1995. Penelitian Hukum Normatif, Jakarta: Raja Grafindo Persada.

Tjip Ismail. 2011. Analisis dan Evaluasi UU No. 28 Tahun 2009 tentang Pajak Daerah dan Retribusi Daerah. Jakarta: Badan Pembinaan Hukum Nasional

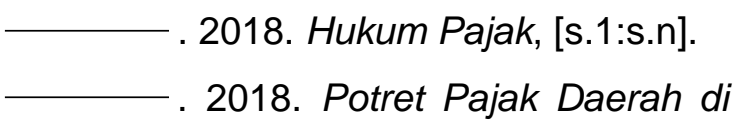
Indonesia. Jakarta: Prenadamedia Group.

\footnotetext{
${ }^{47}$ Tjip Ismail, op. cit., hlm. 175.
} 
Artikel Jurnal:

Agnes Fitryantica. 2019. "Harmonisasi Peraturan Perundang-Undangan Indonesia Melalui Konsep Omnibus Law", Jurnal Gema Keadilan, 6(3).

Ainur Rofieq. 2011. "Pelayan Publik dan Welfare State". Jurnal IImu Pemerintahan, 2(1).

Putu Eka Pitriyantini. 2020. "Mewujudkan Kepastian Rancangan UndangUndang Omnibus Law Bagi Kesejahteraan Masyarakat Indonesia", Majalah IImiah Universitas Tabanan 17(1).

Sri Kusriyah. 2016. "Politik Hukum Penyelenggaraan Otonomi Daerah dalam Perspektif Negara Kesatuan Republik Indonesia". Jurnal Pembaharuan Hukum, 3(3).

Vincent Suriadinata. 2019. "Penyusunan Undang-Undang Di Bidang Investasi: Kajian Pembentukan Omnibus Law Di Indonesia." Refleksi Hukum: Jurnal Ilmu Hukum 4(1).

\section{Skripsi/Tesis:}

Via Eviana. 2015. Analisis Kebijakan Pengalihan PBB P-2 di Kota Metro. Skripsi, Fakultas Ekonomi dan Bisnis, Universitas Lampung, Lampung.

Setiono. 2004. Rule of Law (Supremasi Hukum). Tesis, Magister Universitas Sebelas Maret, Solo.

Makalah:

Machfud Sidiq, Oktober 2002, "Optimalisasi Pajak Daerah dan
Retribusi Daerah dalam Rangka Meningkatkan Kemampuan Keuangan Daerah".

\section{Internet:}

Arasy Pradana A. Azis. "Mengenal Omnibus Law dan Manfaatnya dalam Hukum Indonesia",https://www.hukumonline .com/klinik/detail/ulasan/lt5dc8ee102 84ae/mengenal-iomnibus-law-i-danmanfaatnya-dalam-hukumindonesia/, diakses pada 29 Maret 2020.

Arum Sutrisni Putri. "Pengertian Otonomi Daerah dan Dasar Hukumnya", https://www.kompas.com/, diakses pada 30 Maret 2020.

Cecep Darmawan, "Omnibus Law Untuk Siapa",

https://mediaindonesia.com/read/det ail/296862-omnibus-law-untuksiapa, diakses pada 19 Juli 2020.

Fitria Novia Heriani. "Omnibus Law Perpajakan Bakal Intervensi Aturan Pajak di Daerah", https://www.hukumonline.com/berita /baca/lt5e114f2683adf/omnibus-lawperpajakan-bakal-intervensi-aturanpajak-di-daerah/, diakses pada 30 Maret 2020.

Kementerian Dalam Negeri Republik Indonesia. "Menjaga Momentum, Meningktakan Kepercayaan, Paket Kebijakan Ekonomi (PKE)", https://www.kemendag.go.id/, diakses pada 28 November 2019. 
Kementerian Koordinator Bidang

Perekonomian Republik Indonesia.

"Perkembangan Pelaksanaan

Kebijakan Deregulasi September

2015", $\quad$ https://www.ekon.go.id/,

diakses pada 27 November 2019.

M-30. "Menelusuri Asal-Usul Konsep

Omnibus Law',

https://www.hukumonline.com,

diakses pada 29 Maret 2020.

Redaksi DDTCNews. "4 Aspek Krusial untuk Kurangi Risiko Rasionalisasi Pajak Daerah", https://news.ddtc.co.id/4-aspek-

krusial-untuk-kurangi-risiko-

rasionalisasi-pajak-daerah-19168,

diakses pada 30 Maret 2020.

Yusuf Imam Santoso. "Sah! RUU

Omnibus Law Perpajakan Berisi

Sembilan

Undang-

Undang",https://nasional.kontan.co.i

d/news/sah-ruu-omnibus-law-

perpajakan-berisi-sembilan-undang-

undang?page $=$ all, diakses pada 30

Maret 2020. 